\title{
Hatırda Kalanlar: Bulgaristan Muhaciri Kadınların Anlatılarında Göç ${ }^{1}$
}

\author{
DOI: 10.26466/opus.595302
}

\author{
$*$ \\ Sercan Eklemezler * \\ * Arş. Gör., Bursa Teknik Üniversitesi, İTBF, Yıldırım / Bursa / Türkiye \\ E-Posta: sercan.eklemezler@btu.edu.tr O ORCID: 0000-0003-3198-8413
}

\section{$\ddot{O ̈ z}$}

Ortak deneyimin sürekliliğini bölen mekânsal bir yer değişstirme olarak göç aynı zamanda, grup hafızasında bir "baskın anı" olarak da değerlendirilebilmektedir. Göç ve göçle birlikte gelen yeni kent yaşamı, göçmenin zamana ve mekâna dair algı ve alışkanlıklarını değiştirmektedir. Bununla birlikte hatırlananlar ve unutulanlar yeni bir bağlam içerisinde tekrardan üretilmektedir. Bulgaristan'dan Türkiye'ye göç eden kadınların yaşam deneyimleri temelinde yapılandırılan bu çalışmada hafiza, yer değiştirmeyle (göç) ilişkisi çerçevesinde ele alınmaktadır. Buna bağh olarak hafizanın toplumsal olarak grup etkileşimlerine ve mekâna dağılmış olabileceği görü̧̧ü üzerinde durulmaktadır. Burada, çalışmanın amaçlarına uygun düşecek şekilde niteliksel bir araştırma desenine başvurulmuş, katılımcilarla derinlemesine görüşmeler gerçekleştirilmiştir. Görüşmelerde farklı tarih aralıklarında Bulgaristan'dan Türkiye'ye gö̈ç eden 10 kadın katılımcının, göç öncesi, göç süreci ve göç sonrası ile ilgili deneyimleri ele alınmıştır. Ilgili üç sürece dair hatırlananlar arasında Bulgaristan'daki köy yaşamı ve bu yaşamı şekillendiren tütün işi; Bursa'ya yolculuk ve yolculuk sonrası Bursa'da yaşam mücadeleleri ile yeni yaşama uyum temaları öne çıkmıştır. Sonuç itibariyle bu çalışma, toplumsal hafızanın -ontolojik tartışmalarından bağımsız olarak-, grup etkileşimlerinde ve mekânın yapılanmasında dağılabileceği ve bugünden kurulabileceği iddiasını ortaya koymaktadır.

Anahtar Kelimeler: Hatırlama ve unutma, Yer değişstirme, Göç ve göçmen, Bulgaristan muhaciri kadinlar

\footnotetext{
${ }^{1}$ Bu çalışma araştırmacının Haziran 2018 tarihinde tamamladığı "Toplumsal Hafıza ve Mekân: Bulgaristan Gö̧̧meni Kadınların Deneyimleri ve Bursa Göç Tarihi Müzesi" başlıklı yüksek lisans tez çalışmasının bir bölümünden üretilmiştir.
} 


\title{
Remains in the Memory: Migration in the Narratives of the Immigrant Womens from Bulgaria
}

*

\begin{abstract}
Migration as a spatial displacement that divides the continuity of common experience can also be viewed as a "dominant memory" in group memory. Migration and the new urban life that comes with the migration change the migrants' perceptions and habits on time and space. However, remembered and forgotten are reproduced in a new context. In this study based on the life experiences of women who immigrated from Bulgaria to Turkey, memory is discussed in the framework of relationship with a change of location (migration). Accordingly, it is emphasized that memory may be distributed to social interactions and space. Here, a qualitative research design was applied in accordance with the objectives of the study and in-depth interviews were conducted with the participants. In these interviews ten female participants' -who migrated to Turkey from Bulgaria across different date ranges-experiences on premigration, migration process and post-migration are discussed. Among the three processes recalled, the village life in Bulgaria and the tobacco business that shaped it; the migration to Bursa and after the migration, the themes of living struggles and adaptation to new life came to the fore. As a result, this study reveals that social memory -independently from ontological discussions-can be dispersed in group interactions and structuring of space and established from today.
\end{abstract}

Keywords: Remembrance and forgetting, Spatial displacement, Migration and migrant, Muhacir women from Bulgaria 


\section{Giriş}

Bireysel ve toplumsal hatırlama ve unutma süreçleri, hafıza çalışmalarının temel inceleme konuları arasındadır (Neyzi, 2011, s. 1). Bu çalışma da kuramsal dayanağını ilgili süreçlere dair oluşturulmuş yazından almaktadır. Buna bağlı olarak öncelikle hatırlama ve unutmanın içeriği hakkındaki düşünsel miras ele alınmaktadır. Ardından, "baskın anılar" (Halbwachs, 2016) kavramı çerçevesinde göç gibi bazı anıların niçin diğerlerine göre daha fazla anımsandığı üzerinde durulmaktadır. Hatırlamanın, hafızayı şekillendirici rolü vurgulandıktan sonra son olarak kente göçle birlikte gelen modern yaşamın hatırlama ve unutma üzerindeki özgün etkilerinden bahsedilmektedir.

\section{Hatırlama ve Unutma}

Hatırlamaya dair ele alınan düşünsel miras temellerini Platon'dan almaktadır. Platon'un (akt. Barash, 2007, s.14) anımsamadan kastı, ölümsüz ruhun, nihai hakikatin a priori kaynağını hatırlamasıdır. Hafıza konusunda Platon ile benzer bir töz anlayışı taşıyan Augustinus, hatırlama denen mucizeye odaklanırken mutlu hafızayı yüceltmiştir. Ona göre hafızaya iki nedenle hayranlık duyulabilir. Bunlardan biri hafızanın ucu bucağı olmayan bir tapınak kadar geniş olması, bir diğeri ise insanın sadece imgeleri değil tutkuları ve sevinmeden sevinmeyi, üzülmeden üzülmeyi hatırlayabilmesidir (Ricoeur, 2012, s.117).

Augustinus'un düşüncesinde, mutlu hafızanın gücü üzerinde unutuşun hayaleti dolaşmaktadır. Bu noktada, "unutulmaya gömülmemiş" şeyleri hatırlayabilmek ve hatırlanan şeyin tanınması elbette unutma karşısında elde edilmiş bir zaferdir. Yine düşünüre göre, eğer aranan şey bulunduğunda tanınıyorsa ya da bulunan şeyin aranan şey olmadığı "bu değil" denilerek ifade edilebiliyorsa, gerçek bir unutuştan bahsedilmesi pek de mümkün değildir. Bununla birlikte Augustinus (akt. Ricoeur, 2012, s. 118-119), anıları gömen kesin bir unutuşun varlığından da emindir.

Hatırlama hakkındaki Platoncu görüşün aksine, Locke'un kuramında Aristotales'i aşan bir ampirizmin izlerini bulmak mümkündür. Onun için anımsamanın evreni, duyu deneyiminin ufkuyla sınırlı kalmaktadır 
(Barash, 2007, s. 15). Aristotales ve Locke'un çizgisi modern anlamda hafızanın kapsamını anlamada etkili olmuş olsa da Hegel'le başlayan yönelime kadar, hafızanın, algılanan imgelerin zayıf kopyalarından daha fazlasını içerdiği gösterilememiştir (Barash, 2007, s. 19). Bergson (akt. Barash, 2007, s.18) hafızanın kişisel özdeşliğin alanında ortaya çıktığ konusunda Locke'un görüşüne katılmakla birlikte Hegel gibi, belleğin imgelere indirgenemeyeceğini savunmuştur. Bilişsel psikoloji alanındaki çalışmalar da göstermiştir ki, bireysel hafızamızdaki çoğu şey algılanan imgelerden çok, aslında "olmayan şeylerle" ilgilidir (Boyer, 2015, s. 23).

Locke ve ardıllarının öne sürdükleri iddiaların aksine Barash (2007, s. 18), hatırlamanın kişisel imgelerin hatırlanmasından öteye taşınması gerektiğini savunur ve bireysel anımsamadan çok kolektif anımsamaya vurgu yapar. Nietzche'ye (akt.Barash, 2007, s.20) göre "hafızanın sinirle ve beyinle hiçbir ilişkisi yoktur. İnsan bütün geçmiş nesillerin hafızasını yanında taşımaktadır." ve modern insan, tarihsel ve kolektif belleğinin ağırlığı altında, bireysel ya da toplumsal kimliğine dair tutarlı bir hafızayı muhafaza etmekte zorlanmaktadır.

Halbwachs, hafızanın kolektif oluşu düşüncesiyle, hafızanın öznesi sorunsalında Bergson'un içinde bulunduğu ekolden ayrılmaktaysa da "hatırlama" konusunda ortaklaştıkları bir nokta mevcuttur. Halbwachs (2016, s.183), “Bergson'un da gayet iyi gösterdiği üzere, bir anının geçmişteki yerini ararken, bu anıya komşu olan ve onu konumlandırmamıza olanak tanıyan başka anılarla karşılaşmamız tesadüfen olmaz." diyerek hatırlama hakkında mekânsal bir analoji kurmuştur. Halbwachs (2016, s.183), geçip giden zamanı diğer tüm anıların yaslandığı bir dayanak noktası gibi belirleyen "baskın anılar" konusunda Bergson'a katıldığını ifade ederken onun zamansal vurgusunun yerine, mekânsal bir vurgu yapmaktadır:

Baskın anılar, büyüklüğ̈̈yle ya da sakinlerinin sayısıyla ayırt edilen ve bunlarla ayn harita üzerinde diğer yakın ve eşit önemdeki şehirleri bulacağımıza emin olacă̆ımız kadar farklı şehirleri ayırt etmemize olanak tanıyan şu ya da bu şehre karşıllk gelir (Halbwachs, 2016, s. 183).

Halbwachs (2016, s.185) için, bir şehrin sokaklarında bir kişiyi bulmak sokakları dolduran kalabalığın hareketli olmasından ve sokakların durmadan yer değiştirmesinden dolayı zordur; çünkü anılar, yeni anılarla ilişki içerisinde değişmekte, farklılaşmakta ve yeniden kurulmaktadır. 
Ancak Halbwachs'ın mekânsal analojisinde, mekânın önemi sınırlıdır; onun için asıl önemli olan, bu şehirlerin sokaklarında kolektif gruplar tarafından her an yeniden kurulan ilişkilerdir:

Anılar birbiriyle ilişkilendiren şey, zamanda yan yana olmaları değil, bir grup için, o an ilişkide olduğumuz ya da önceki gün veya günlerde ilişkide bulunduğumuz insan grubu için ortak düşünceler bütününe bağlı olmalarıdır (Halbwachs, 2016, s.186).

Grubun üyelerinden her biri, anılarının yönünü ister istemez kolektif hafızaya doğru çevirmektedir. Geçmişi nasıl hatırladığımız, bize okulda öğretilen tarihten, medyadan, aile ve sosyal çevremizden aktarılan kültürle yakından ilişkilidir (Portelli 1991, akt. Neyzi, 2011, s.2). Ancak, geçmişte, kolektif gruplar tarafından gerçekten de çok önemli olduğu düşünülen ve vurgulanan olay ve figür yığınlarının hepsi "baskın anı" haline gelmemiş; tersine, mevcut düşünce ve algı kalıplarıyla hatırlanamayacak kadar hızla hafızadan kaybolmuşlardır. İçlerinden bazılarının daha iyi hatırlanmasının nedeni yaşandıkları andan ziyade hatırlama anıyla ilişkili gözükmektedir: "Eski olayları, tam olarak yeniden üretecek olan şey, geçmiş durumların kronolojik dizisi değildir; içlerinden yalnızca güncel kaygılarımıza karşılık gelen ve yeniden ortaya çıkabilecek olanlardır" (Halbwachs, 2016, s.184).

Hatırlama konusunda duyguların da önemli bir yeri olduğu düşünülmektedir. Bir olay duygusal önem taşıdığındaya da taşımaya devam ettiğinde, bütün ayrıntıları ve açıklığıyla hatırlanmaktadır (Schacter, vd., 2015, s.129). Kulik (1977 akt. Schacter, vd., 2015, s.129) tarafından geliştirilen "flash anılar" terimi, "insanların çok şaşırtıcı ve duygusal heyecan yaratan olaylarla ilgili anılarında bulunan 'resim kadar canlı olma' özelliğini yansıtmaktadır". Duygusal anılar, içerikleri ne olursa olsun, hatırlamayı kolaylaştırıcı bazı süreçleri devreye sokmaktadır; ancak, özellikle olumsuz duygusal içerikli bilgiler, belirgin duygusal nitelik taşımayanlara kıyasla çok daha ayrıntılı şekilde hatırlanmakta ve "baskın anılar" halini almaktadır (Schacter, vd., 2015, s. 135-136).

Bellek ile unutmayı birbirinin zıttı olarak görmeyi gereksiz bulan Huyssen'e (1999, s.178) göre, şimdi ile geçmiş arasında sürekli bir diyalog söz konusudur. Bu kavramlar durağan, zit ve birbirini dışlayan kategoriler değil, diyalektik bir ilişki içindeki ikilikler olarak 
düşünülmelidir. Halbwachs (2016, s.346), bizi ilgilendiren geçmiş olayların belleğimizdeki yerini, onların kolektif hafıza içindeki yerine referansla hatırlayabileceğimizi ileri sürmüştür. Unutmaksa, onun için bu kolektif referans çerçevesinin değişimiyle açıklanabilmektedir ve o da kolektiftir:

Bir anı, esasen birbirleriyle kesişen, kısmen birbirini kapsayan çok sayıda çerçevenin karşılaşma noktasında ortaya çıktı̆̆ı ölçüde zengindir. Unutmanın kendisi ya dikkatimiz çerçeveler üzerinde sabitlenemediği ya da başka bir yere sabitlendiği için (...) bu çerçevelerin ya da bir kısminnn kaybolmasıyla açıklanmaktadır (Halbwachs, 2016, s.346).

Kısacası Halbwachs için unutma, anıyı kuran toplumsal çerçevenin bir dönemden diğerine değişmesiyle açıklanmaktadır; çünkü anılar, olduğu gibi muhafaza edilmemekte, şu anda yeniden kurulmaktadır. Halbwachs'ın, "bellekteki verinin, hatırlama anının özellikleriyle harmanlanarak yeniden oluşturulduğu" görüşü, günümüzde kısmen ortak bir kabul haline gelmiştir (Rose 2003, akt. Neyzi, 2011, s.1). Bilişsel psikolojinin gözünden bakıldığında da "hafıza, basitçe geçmiş olayların saklanmasına yardımcı olan bir araç" değil, şimdiki ve gelecekteki davranışlarla ilişkili bir işlevdir (Boyer, 2015, s. 5-6). Bu perspektiften yaklaşıldığında, geçmiş hem şu anda yeniden kurulmakta hem de geleceğimizi şekillendirmektedir.

Roediger ve arkadaşlarına (2015, s.191) göre, psikologlar tarafından gerçekleştirilmiş hatırlama ile ilgili çok sayıda deneysel çalışma, kolektif bellekle ilgili konuların dile getirilmesinde yardımcı olabilmektedir. Örneğin, "tekrarlanan geri getirme, kolektif belleğin oluşturulmasında ve şekillendirilmesinde de önemli bir rol oynamaktadır". Bir anıyı bellekten geri getirme nötr bir olay değil; aksine, bellek izinin değişmesine yol açan yeni bir yapılandırmadır (Bjork, 1975). Huyssen'in (1999, s.177) de belirttiği üzere, bir toplumun kolektif belleği, bireysel bellek kadar istikrarsızdır. Bu belleğin şekli de hiçbir biçimde kalıcı değildir. Toplumsal bellek, incelikli, bazen de o kadar incelikli olmayan yeniden kurmalara tabidir. Kısacası toplumsal bellek de bireysel bellek gibi her hatırlama anında yeniden şekillenmektedir. 


\section{Toplumsal Bellek Taşıyıcıları ve (Modern) Unutuş}

Connerton (1999, s.10) "herhangi bir toplumsal düzene katılmış bulunanların, ortak anıları olduğunu varsaymaları"nın "örtük bir kural" olduğunu belirtmesiyle toplumsal belleğin varlığı konusunda Halbwachs'ın $(2007 ; 2016)$ görüşlerine katılmaktadır; ancak toplumsal belleğin taşıyıcıları konusunda yeni fikirler ileri sürmüştür. Yazar (Connerton, 1999), Toplumlar Nasıl Anımsar isimli eserinde, toplumsal belleğin "bilinç dışı" ve "siyasal" yönlerini askıya alıp özellikle "anma törenleri" ve "bedensel pratikler" üzerinde durmuştur. Bergson'un imge yoluyla hatırlamasina Halbwachs ne kadar önem verirse, Connerton (1999, s.47) da itki yoluyla hatırlamaya bedensel pratiklerde gömülü oluşuyla o kadar önem vermektedir. Onun için belleğin kişisel, bilişsel ve alışkanlıklarla ilgili üç boyutu vardır. İlkini psikanalistler, ikincisini psikologlar incelerken üçüncüsü yani alışkanlıklarla ilgili tarafı ise "savsaklanmış"tır. Zira Connerton'a göre toplumsal kuram, "anlamlı" insan eylemleriyle uğraşmayı tercih etmiştir. Oysa bedensel pratiklerimize ve anma törenlerimize gömülü bu üçüncü bellek yani "alışkanlık belleği" Connerton (1999, s.64) için oldukça önemlidir.

“Toplumsal alışkanlık belleği” Connerton (1999, s.64-65) için toplumsal kuralların başarılı ve inandırıcı bir biçimde yerine getirilebilmesi ve devamlılığı için gerekli tamamlayıcı bir öğedir. Bu açıdan Connerton (1999, s.70) anma törenlerini ve bedensel pratikleri "toplumsal çerçevelerin" devamlılı̆̆ını sağlayan birer "aktarma eylemi" olarak tanımlamıştır. Modernite Nasıl Unutturur adlı eserindeyse, modernitenin toplumsal anlam çerçevelerini nasıl yerinden edip aktarma eylemini sekteye uğratarak unutmaya hizmet ettiğinden bahsetmiştir (Connerton, 2012). Yazar bu savında, "kültürel amnezi"nin (hafıza kaybının) modernite öncesi dönemlerde de var olduğunu yadsımamaktadır; ancak odak noktasını moderniteye özgü yapısal unutkanlıklara kaydırmayı amaçlamaktadır. Connerton'a (2012, s.47) göre, "birçok modern maddi pratiğin kültürel unutkanlık süreciyle bağı vardır".

Modern topluma ait dört kurumsallaşmış zaman çizelgesinden bahseden yazar (Connerton, 2012, s.47), bu "zamansallıklar"ın, zamanın akışını hızlandırarak moderniteye özgü "kültürel unutkanlığa" hizmet ettiğini ifade etmektedir. Bu zamansallıklardan ilkini "emek sürecinde" 
açıklayarak modernitenin kurucu öğesi olan devasa emek sürecinin nasıl görünmez hale geldiğinden bahsetmiştir. Bir metanın, baştan sona üretimine tanık olunmadığı sürece ürettiklerine "yabancılaşan" toplum, bunun arkasındaki emeği giderek daha az fark etmektedir (Connerton, 2012, s.47-59). İkinci olarak, modernitenin "tüketim zamansallıkları"nın, vurguyu "kullanım değeri"nden "değişim değeri" ne kaydırmasından ve moda sayesinde sürekli "zamanın gerisinde" kalma hissiyle gelen değişimleri takip etme baskısıyla "bellek dünyalarının" nasıl bir hızla yenilenmesi gerektiğinden bahsetmiştir (Connerton, 2012, s. 59-72). Modernitenin unutkanlıkla ilgili üçüncü zamansallığı, hızla aşınan kariyer yapılarıyla ilgilidir (Connerton, 2012, s.73). Modernite sonrasinda iş ve kariyer yapıları artık bir insan ömründen çok daha kısa sürmektedir ve bireylerin sahip olduğu yetenekler ve bilgi birikimi çok kısa sürelerde işlevsiz kalabilmektedir. Connerton'un (2012, s.84) moderniteye özgü unutkanlığa sebep olan son zamansallık kategorisi, tüketim zamansallığını da kapsayan, onun da üzerinde yer alan medya zamansallığıdır. Bellekteki "amnezi etkisinin gücü, televizyonun çoğalan imgelerine gündelik olarak maruz kalmamızla artar." (Connerton, 2012, s.87) Unutkanlığın kültürel olarak kurumsallaştırılmasının ardında geçmişin medyada çabucak gözden kaybolan imgelere dönüştürülmesi süreci önemli bir etken olmaktadır (Connerton, 2012, s.89).

Son olarak Connerton (2012, s.98-140) giriştiği modernite eleştirinde, modernitenin de öteden beri yaptığı gibi, mekânı zaman karşısında önemsiz ve tekdüze bir olgu olarak ele alma hatasına düşmeyerek moderniteye özgü unutkanlığın, mekânla olan ilişkisini üç başlıkta ele almıştır: İnsan yerleşimlerinin genişleyen çapı, mekânsal hareketliliğin artan hızı ve son olarak, "kurulu çevrenin belirli aralıklarla kasti olarak yıkılması". Tüm bu olgular birbiriyle ve modern kapitalizmle ilişkili olarak meydana gelmektedir:

Insan yerleşimlerinin boyutlarının artması, hızın üretilişi ve kurulu çevrenin defalarca kasti olarak yıkılışı herkesi etkisi altına alan, yaygın ve güçlü bir kültürel amnezi yaratır; kapitalist üretim süreci de bahsettiğimiz bu üç sürecin strayla ortaya çıkmasına neden olur. Modernite ya da en azından kapitalist üretim sürecinin ekonomik genişlemesiyle temsil edilen bu bileşeni, kültürel amneziyi kazara değil zorunlu olarak üretir. Unutkanlık kapitalist üretim sürecine içkindir; 
bu durum kapitalizmin yaşam alanlarına ilişkin bedensel deneyimlerimizle bütünleşir (Connerton, 2012, s.124).

\section{Göçmen ve Hafızası}

Birleşmiş Milletler göçmeni; sebepleri, gönüllü olup olmaması, göç yolları, düzenli veya düzensiz olması fark etmeksizin yabancı bir ülkede bir yıldan fazla ikâmet eden bir birey olarak tanımlamaktadır (Adıgüzel, 2016, s. 5). Göç temelde bir insan hareketliliğidir ve bu hareketlilik, "vatana/yuvaya dönüş" olarak adlandırıldığında (Roseman, 1971, s. 589590) dahi mekânsal bir kopuşu içermektedir. Göç, insanların, sosyal, ekonomik, siyasi ve doğal nedenlerden dolayı coğrafi olarak yer değiştirmesi biçiminde tanımlanabilmekteyse de göçmenler, bir fiziksel mekândan bir başkasına giderken sadece elle tutulur, gözle görülür eşyalarını değil, tüm hayat tecrübelerini, yaşam biçimlerini, dillerini, kültürlerini, anılarını ve hayallerini de götürmektedir (Adıgüzel, 2016, s. 3). Buna karşın birçok şeyi de geride bırakmak zorunda kalmaktadırlar. Chambers'ın (2014, s.13) Edward Said'den alıntıladığı gibi göçmenlik "kesintili bir var olma" durumu ve geride birakılan yerle bir kavgaya tutuşma biçimi olarak modern kültürün güçlü bir motifi haline gelmiştir. $\mathrm{Bu}$ nedenle göç çalışmaları, insana ve onun mekânsal hareketliliği sonucunda oluşturduğu ilişkilere, götürebildiklerine ve götüremediklerine, hatırladıklarına ve unuttuklarına eğilme sorumluluğundadır.

Volkan'a (2017, s.29-54) göre yerinden yurdundan ayrilma süreci hem zorunlu hem de gönüllü göçü kapsamakta ve kişilerin, yitirilmiş kişiler ya da imgeleri yoğun bir biçimde içsel olarak gözden geçirdiği bir yas süreci olarak incelenebilmektedir:

Yerinden yurdundan ayrllmış tüm bireylerin psikolojilerinin altında yatan kilit bir unsur vardır. Bir yerden ayrılarak yabancı bir yere gitmek; aile üyelerinin ve arkadaşlarm yitirilmesi, aşina olunan dilin yitirilmesi, ait olunan çevredeki şarkıların, kokuların, yemeklerin yitirilmesi, önceki kimliğin ve bunu destekleyen sistemin yitirilmesi gibi pek çok kaybı içerdiŭi için yerinden, yurdundan ayrılma deneyimlerinin hepsi, gö̧̋menin ya da mültecinin yas tutma ve yas tutma sürecine direnç gösterme becerisi bağlamında incelenebilir (Volkan, 2017, s.30). 
Volkan'a göre (2017, s.41) yetişkin göçmenlerin, geride bırakmış oldukları şeylere dair imgeleri hatırlaması zorunludur. Yerinden yurdundan olan kişi, yitirilen mekânı ve o mekânda gerçekleşen ilişkileri hatırlamak için anılara başvurabilmektedir. Hatıralar, gelinen mekân ve o mekânda gerçekleşen ilişkilerle devamlılık sağlamaktadır. Ancak, bu hatıralar yas sürecinin dışsallaştırıldığı bir depo işlevi gördüğünde, karmaşık duygusal anlamlar yüklendiğinde "bağlantı kurucu fenomen" haline gelmektedirler (Volkan, 2017, s.51-52). Göç bir yas süreci olarak ele alındığında, geride kalanlara dair "bağlantı kurucu fenomen" kavramsallaştırmasına ihtiyaç vardır ve her hatırayı bu kapsamda ele almak mümkün değildir. Bağlantı kurucu fenomenler bazen bir şarkı, bir el hareketi, hatta belirli bir hava durumu, daha ziyade bir nesne olabilmektedir (Volkan, 2017, s.49). Bu fenomenleri, hatıralardan ayıran şey göçmenin geride bırakılan yere dair hesaplaşmasında onlardan ne ölçüde faydalandığı ve bu hesaplaşmanın gündelik yaşamdaki yoğunluğuyla ilgilidir.

Volkan (2017, s.19) hayatları boyunca hiç karşılaşamayacak olsalar da aynı kabileye/aşirete ait, etnik, dinsel, ulusal ya da ideolojik duyarlılıkları paylaşan yüz binlerce bireye atıfta bulunmak için "büyük grup" terimini kullanmaktadır. Bulgaristan Türkleri birçok yönden Türkiye Türkleri ile ortak büyük grup kimliğine sahiptir ve bunu göç sonrası süreci kolaylaştırıcı bir etken olarak ele almak mümkündür. Diğer taraftan, yetişkin bir göçmen için aynı dilin konuşulduğu durumlarda bile dilin müziğini (aksan, ritim) yakalamak hiçbir zaman mümkün olmamakta ve bu da ortak büyük grup kimliğinden ayrılışın en kolay gözlenen öğelerinden biri olabilmektedir. Ortak büyük grup kimliğine sahip olmak, göçmen için geride bırakılanlara dair yas sürecini bir ölçüde kolaylaştırabilmektedir. Ancak, bu süreç her zaman hatırlama ve unutmaya dair çetin bir mücadeleyi içermektedir.

\section{Yöntem}

Çalışma, araştırma konu ve amacına uygun olarak niteliksel araştırma desenine göre yapılandırılmıştır. Buna bağlı olarak da ilgili desen içerisinde yer alan derinlemesine görüşme tekniğine başvurulmuştur. Araştırma grubunun seçiminde kartopu örneklemi uygulanmış, 
toplamda 10 kadın katılımcı ile görüşülmüştür. Araştırmanın ilk tasarımında, kadın ve erkek göçmenlerin göç süreciyle ilgili deneyimlerine ulaşılması amaçlanmıştır. Ancak, görüşmelerde göçmen erkeklerin isteksiz davranmaları ve konuya dair anlatılarının sınırlı olması erkek katılımcıların bu çalışma dışında bırakılmasına yol açmıştır. Dolayısıyla çalışma kadın katılımcılar üzerinden ilerlemiştir. Görüşmeler göç öncesi ev, çalışma, sosyal yaşam ve ilişkilerinin yanı sıra göç süreci ve göç sonrasına dair yaşam deneyimleri ve anıların aktarımıyla şekillenmiştir.

Çalışmaya dahil edilen katılımcılarla ilgili bilgi verilecek olursa; katılımclar beşer kişilik iki grup içerisinde değerlendirilebilir. Gruplardan biri, 1968 yılında Bulgaristan'la Türkiye arasında imzalanan Yakın Akraba Göçü Antlaşması'yla gelenleri kapsamaktadır. Diğer grup ise 1989 zorunlu göç süreci ve sonrasındaki 1990'lı yıllarda göçü deneyimleyenlerden oluşmaktadır. Göçmen kadınların yaşları 38 ile 78 yaş aralığında değişmektedir. Detaylandırılacak olursa, 1969-1978 yılları arasında parçalanmış aileleri birleştirmek amacıyla 130.000 kadar Türk'ün Bulgaristan'dan Türkiye'ye göç ettiği dönem içinde Bursa'ya yerleşen beş kadının yaş aralığı 55 ile 78 arasında değişmektedir. Yaklaşık 300.000 Türk'ün sınır dışı edildiği 1989 zorunlu göç süreci ve sonrasındaki 1990'l1 yıllarda göçü deneyimleyen beş kadının yaş aralığı ise göç hareketlerinin de günümüze yakınlığına paralel bir şekilde 38 ile 62 arasında değişmektedir.

Katılımcıların tamamı Bulgaristan'ın yoğun Türk nüfusuna sahip olan Kırcaali ilinden gelip kalıcı olarak Bursa'ya yerleşmiştir. Burada belirtilmesi gereken önemli bir nokta Kırcaali ilinin, daha ziyade köy ve kasaba yerleşimlerinden oluştuğudur. Dolayısıyla Kırcaali bölgesinden gelen katılımcilar köy ve kasabalardan gelip Türkiye'de (modern) kent yaşamına dahil olmuşlardır.

\section{Bulgular ve Tartışma}

Çalışmanın bu başlı̆ğ bulgulara ayrılmıştır. Burada elde edilen bilgiler dört alt başlık altında işlenmiştir. 


\section{Göç Öncesi Süreç: Bulgaristan'da Köy Yaşamı}

Bulgaristan'daki köy ve/veya kasabalarda iki ya da tek katlı müstakil evlerde yaşayan göçmen kadınların aile tipi ve ailedeki birey sayısı çeşitlilik göstermektedir. Anne, baba ve iki çocuktan oluşan çekirdek aileler olduğu gibi bunlara babaanne veya dedenin eklendiği geniş aile ya da yenge, elti, görümce ve yeğenlerin de eklendiği geniş ailelere de rastlanmaktadır. Ancak, çekirdek aile tipinin gözlemlendiği ailelerde dahi üç eltinin birbirine çok yakın oturduğu ya da köy hayatına yönelik işlerin yoğunlaştığ 1 dönemlerde geçici olarak dede, anneanne gibi başka akrabaların da aile nüfusuna eklendiğinden bahsedilebilmektedir. 1978 yılında göç eden bir katılımcı, eşi maden ocaklarında çalıştığı için, eşi ve iki çocuğuyla birlikte Madan' da bir apartmanda; 1990 yılında göç eden bir diğeri ise tekstil fabrikasında çalıştı̆̆ı için maaşından kesilen bir bedel karşılığında diğer iki kadın işçiyle paylaştığı bir lojman dairesinde kaldığını belirtmiştir. Türkiye'ye göç etmeden önceki son evler ve yerleşim yerlerinden daha çok hatırlanan çocukluk ve gençlik dönemlerinin geçtiği yerler olmuştur:

Önce Ardino'daydık (Ĕ̆ridere), daha doğrusu köydeydik. Köyden kasabaya geldik. 1958 senesinde Dedeler Köyü'nden Ardino Kasabası'na geldik. Orda gençliğim geçti. Sonra babam çiftlik aldı Ardino'dan. (Yaş 73, Gö̧̧ yılı 1978).

Doğduğumda, Dedeler'de büyüdüm. Orada büyüdüm. 18'de İrdere'ye (Ĕgridere) evlendim. İrdere'ye, İsollar'a işte evlendim. Dedeler'de tabi, 18'e kadar yedik içtik, ana baba yaninda. (Yaş 78, Göç yll 1973).

Köydeki tarımsal üretimin başında, ailelerin birlikte çalıştı̆̆ 1 "tütün işi" gelmektedir. Ancak katılımclar arasında sadece "tütün işleyen”, yani tüm aile gelirini tütünden sağlayan yalnız bir aile vardır. Bunun dışında çocukluk çağında olanlar hariç tüm kadınlar aileleriyle birlikte tütünde çalışma/tütün işleme ve diğer geçimlik patates, yulaf, domates, biber, fasulye üretiminde bulunma veya inek, tavuk ve koyun gibi hayvan bakmanın yanında kasabada devletin tekstil, dokuma veya "Monopol" tabir ettikleri tütün fabrikalarında çalışmışlardır:

Dört sene Monopol'de çallştım, Tekel gibi. Evlenmeden önce de evlendikten sonra da çok çalıştım. Sevgin (kızı) olduğu zaman bıraktım. Çok çalıştım. O askere gitti, kaynanamlarla beraberdik. 5 sene durduk. Çalıştım. Ev yaptım. Askerden geldi, öyle işte. Tütün yapıyorduk. Sigara içilen tütünlere ne diyorlar acaba, tütün işte. Yani dikerdik, kırardık, pastal yapardık, denk yapardık. Monopol alırdı onları. 
Onlara para verirdi. İkinciden üçüncüden verirse iyi para verirdi. Sevgin olunca Monopol'ü bıraktım. Evde tütün çalıştım, inek baktım, tavuk baktım, küçük hayvan baktım, çocukları büyüttüm. (Yaş 78, Göç yılı 1973)

Ben tekstilde çalıştım. Zaten hemen geldik buraya. Doğum yapmıştım o zaman. Doğum iznindeydim. Az bir şey çalı̧̧ım yani. Kasabada yaşıyorlardı eşimin ailesi; ama içeriye büyük yerlere gidip tütün çalı̧̧ıorlard. "Brigadirlik" yapıyordu kayınpeder. Yani, ustabaşı gibi işçi götürüyordu. Ben de çalş̧ıyordum hem onlarla, zaten tütün işini çok severim ben. (Yaş 51, Göç yıll 1989)

Diğer göçmen kadınların yanı sıra göç ettiklerinde ilk ve ortaokul çağında olan iki kadının verdikleri bilgiye göre, çocuklar da köy yaşamında çalışma hayatının tamamıyla dışında kalamamışlardır:

Tütün çalışıyorduk. Annemler, babamlar tütün tarlasında, işte ben de ara sıra yardıma gidiyordum. Öyle geçiyordu zaman. Hem oyun oynuyordum hem çalş̧ıyordum hem okuyordum yani; ama çocukluğum çok güzeldi. (Yaş 39, Göç yılı 1992)

Komşuluk ilişkileri tüm kadınların değindiği ve özlemini çektikleri konular arasında yer almaktadır. Köy yaşamının getirdiği şartlar ve tarımda makineleşmenin eksikliği imece usulü çalışma temelinde gelişen komşulukları doğurmuştur. Tarladan ürünlerin taşınması, tütünlerin dizilmesi, "pastal" denilen tütün balyalarının hazırlanması hatta tütünlerin sırıklara dizilip "ramka" denilen üç metre genişliğindeki tahta çerçevelerde kurutulması sırasında, yağan yağmurlardan koruma amacıyla kapalı alanlara taşınması, her zaman komşularla birlikte yapılan işler arasındadır. Bunlar dışında çocukların bakımı gibi işlerde de komşu kadınlar arasında yardımlaşma görülmektedir. Ancak, göç sadece göç edenlerin değil geride kalanların da komşuluk ilişkilerinde değişiklikler meydana getirmiş, nüfusta meydana gelen azalma, mekânda gerçekleşen ilişkileri de etkilemiştir. Gidenlerin arkasından dökülen gözyaşlarıyla eskinin canlı komşuluk ilişkileri yavaş yavaş solmuştur:

Dediğim gibi dağılana kadar, gurbetçilik başlayana kadar... Sonra bakıyorsunuz bu evde insan yaşıyor, yan taraftaki boş. Diğerinde var, iki tanesi boş. Öyle parça parça kopmaya başladı birlik beraberlik. (Yaş 39, Göç yılı 1998)

Akrabalar ve komşularla ya da diğer köy/kasaba halkıyla bir arada katılmış oldukları törensel pratikler, katılımcıların hatıralarında önemli bir yer tutmaktadır. Bu pratiklerden biri, kadın için hemen her zaman yeni bir köy/kasabada, yeni bir evde, yeni bir ailenin kurulması ve yepyeni sorumlulukları beraberinde getiren evlilikle ilgili geçiş dönemi 
adetleridir. Düğünün kendisi kadar çeyiz ve eşyalar da kadınların hayatında ve dolayısıyla hafızalarında önemli bir yer tutmaktadır:

Düğ̈̈nler çok güzel olurdu. Kavga olurdu; ama kız tarafı oğlan tarafi... Kız tarafının istediğini oğlan tarafı vermezse çok gürültü yapardı kız tarafı. Kızı alırken istiyorlar, vaat ediyorlar. Ondan sonra son nişanda onu getirmiyorlar. Bana getirmediler. Bu beşibirlik, 2 de lira senin dediler, aldattılar. O zaman yaşlılar vardı çok. Dünür getirirdi, nişanlara baktım altınlar yok. Altından başka sırt baş getirirlerdi. "Ferece" derdik, entari, altında dürmeli don. Burasının pijaması değil. Kız tarafinın da çeyizi olurdu. 7-8 yorgan, döşek, 20-25 yastık olurdu. Çemberin ayrı yaşmağın ayrı, ondan sonra krep derdik krebin ayrı. Bulgaristan'da böyle beyaz eşya yok ki. Örtü, döşek, yastık çok fazla onlar. Bir takımını kaynanaya veriyorsun, Allah ne verdiyse. (Yaş 78, Göç yılı 1973)

Birinin evine çeyiz bakmaya gitmişler kim hatırlayamayacağım, babam hep anlatırdı. Hiç duvar panosu yok, yapmamış demişler, kanaviçe. Kızın babası da benim kızım kendisi duvar süsü, demiş. Öyle güzel, demiş. (Yaş 78, Göç yılı 1973)

Düğünler yeni bir ailenin kurulmasının toplumsal onayıyla ilgili olduğu kadar çoğu zaman köyün/kasabanın sınırları ile çizilen hayatlarda başka karşılaşmalara ve yeni beraberliklere de fırsat yaratmaktadır. Ancak, bunun en kurumsallaşmış halini bugün yetmişli yaşlarda ya da altmışlı yaşların sonunda olanların hafızalarında yaşayan bir seremonide bulmak mümkündür. Bayramlarda köyün "harman" denilen düzlüğünde kız ve erkeklerin birbirlerini "beğenmesi" için karşılıklı gruplar halinde dizilmeleri, "beğendiklerine” küçük yaştaki çocuklar aracılığıyla mendil göndermeleri ve kızların maniler okuması zamana yenik düşmüş; karşılaşmalar yılda bir kez gerçekleşen panayırlarda sürmüştür. Tütün işleri bitmiş, patateslerini tarladan toplamış olan halk en güzel kıyafetlerini giyip süslenerek 9 Eylül'de -katılımcıların deyimleriyle"lapır lapır" kasabada kurulan panayıra akın etmektedir. Panayırlar salt bir eğlence değil, bir yıllık çalışmanın ödüllendirilmesidir ve üretim sürecinden bağımsız düşünülemeyeceği gibi köy ile kasabanın; Bulgarların, Türklerin ve Pomakların karşılaşma mekânlarıdır. Panayırdaki dönme dolap, zincirli salıncak, helvalar, şekerler, oyuncaklar çocukluğunu Bulgaristan'da geçirmiş herkesin hafızasında canlılığını korumaktadir:

Kendimden bahsedeyim, kaç yaşındaydım bilmiyorum. Kasabaya belki geldim; ama ilk defa panayıra geldim. Zincirli sancak (salıncak) vard. En çok 10 
yaşlarındaydım. O sancağın bir koltuğuna asıldım. Kendim döndüm döndüm. İndikten sonra artık o benim sanki malımdı akşama kadar. (Yaş 73, Göç yılı 1978) Seneden seneye panayırlara gidiyorduk. O zaman çok mutlu oluyorduk. Çok bolluk görmüyorduk yani. Şimdi, köyde öyle market falan olmuyordu; ama kasabaya gidince mutlu oluyorduk yani. (Yaş 39, Göç yılı 1992)

Bayramlara dair âdetlerden bir kısmı zamanla değişime uğramış bayram sabahı çocukların her evden toplayıp yedikleri ve aileleri tarafından hazırlanan ağaç şişlere dizdikleri "gulaç"ların (lokma/pişi) yerini şekerlemeler almıştır. Bu dönemi Bulgaristan'da geçiren katılımcılar tarafından "adlarımızı değiştirdikleri zaman" olarak hatırlanan ya da daha önce göç edenler tarafından "adlar değiştiği zaman" şeklinde anılan 1984 ile 1989 yılları arasında yoğun olarak hissedilen asimilasyon politikası sırasında, düğünlerin olmazsa olmazlarından davul-zurna gibi çalgılarla sünnet, kurban kesme gibi dini ritüeller yasaklanmıştır. Bu süreçte çocukların sünnet ettirilmesi görevi çoğu zaman ailenin ninesiyle birlikte yaşlı bir komşu veya akraba kadının ya da çocuğun annesinin nezaretinde kaçak olarak gerçekleştirilmiştir. Erkeklerin Belene Kampı'na gönderilmesi veya işkenceye maruz kalması riskinin görece fazlalığı karşısında kadınlar karakollarda sorgulanmayı göze almıştır. Kurbanlar, bayramın üçüncü günleri gece kesilmiştir. Belediye görevlileri kavurma kokusunu ya da kurban çukurlarının varlığını kontrol ederek kurban kesenlerin cezalandırılmasına çalışmışlardır. Bulgaristan'da yaşayan hemen herkesin Ramazan ayına dair en canlı anılarından biri olan "gezek" âdeti, yoğun asimilasyon yılları dışında zamana direnmiş ve dokuz kadın tarafından dillendirilmiştir:

Ramazanda zannedersem mektep; ama köyün namaz kıldığı, yaşlıların namaz kıldı̆̆ı bir yerdi, mescit gibi. Bir oda çatısı olan; ama oraya mektep diyorlardı. Her akşam köyün yaşliları ezandan önce oraya gidiyorlardi; ama bu gece mesela bizdeyse yemek vermek, ertesi gün öbür komşu, ertesi günü öbür komşu yemek götürüyordu yani tatlısından, çorbasından, böreğinden, pilavından. Ramazan öyle geçiyordu. Gezek derlerdi buna. (Yaş 55, Göç yılı 1973)

Bunlar devam etti. Annemler benden birkaç ay önce geldiler. 97'nin sonlarında geldiler. Ben kaçak yollardan geldiğim için gene böyle bir ramazan ayında yalnız kaldık babamlarla. O zaman da yemek strası bizdeydi. Bizzat kendimiz hazırladık babamla. Çok iyi hatırlıyorum yani. Öyle yemeğini, ayn buradaki gibi. Misafiri nasıl ă̆ırlarsın, her çeşit yemeğini yaparsın, öyle yemeğini yapıp sunuyorduk. Götürüyorduk camiye. Kim geldiyse namazdan sonra erkekler oturup birlikte 
yerdi. Kadınlarsateravihte falan toplanırdı. Ĕ̆ger akşamları çok fazla iş güç yoksa herkes kapısının önüne çıkıp otururdu. (Yaş 38, Göç yılı 1998).

1 Mayıs Emek Bayramı, kasabadaki fabrika işçileriyle birlikte her köyün muhtarı ve brigadiri önderliğinde, köylülerin yetiştirdikleri ürün ya da yarışmada derece alan hayvanlarıyla birlikte, ellerinde Bulgarca "Yaşasın 1 Mayıs" tabelalarıyla geçiş yaptıkları bir gündür. 1 Mayıs Emek Bayramı'nın yanı sıra, 8 Mart Emekçi Kadınlar Günü, 23 Nisan Çocuk

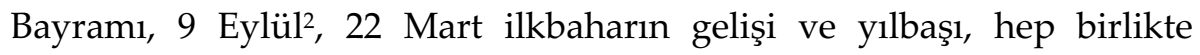
katıldıkları törenler/kutlamalar arasında yer almaktadır. 8 Mart Emekçi Kadınlar Günü'nde, fabrikalarda çalışan kadınlar için varsa fabrikanın yemekhanesinde yoksa başka bir yerde yemek verilmiştir. Bunlardan en ilgi çekici olanı 9 Eylül olup Komünist devrin/dönemin en yoğun asimilasyon politikalarını uyguladığı yıllarda dahi arkasındaki anlam pek de sorgulanmaksızın Türk halkı tarafından da "panayır" zamanı olarak kutlanmaya devam etmiştir.

\section{Göç Süreci I: Yolculuk ve Bursa'ya Yerleşme}

Göçmen kadınların "göç kararı"nda genellikle babaları ya da eşlerini izlediklerini söylemek gerekmekle birlikte her bir göçün bir diğerinden farklı özellikler taşıdığını, her bir göçün biricik ve özgün olduğunu belirtmekte fayda vardır. Araştırmaya konu olan göç deneyimleri, birbirinden birçok yönde farklılaşmakla birlikte, ortaklaştıkları noktaların başında, gidilecek yerlerdeki akrabaların varlığının göç kararında, göçün kendisinde ve göç sonrasında kolaylaştırıcı bir unsur olması ve zihinlerdeki "Anavatan Türkiye” imgesi gelmektedir. Anavatan Türkiye imgesi 1970’li yılların başındaki erken göçlerde öncelikle aile büyüklerinden, babalardan ve eşlerden yayılan bir olguyken var olan ayrımcı pratiklerin artması ve asimilasyon politikasının şiddetlenmesi ile herkes tarafından paylaşılan gündelik hayatın bir parçası halini almıştır. Söz konusu göçler öncelikle göçe zorlayıcı etkenlerin şiddeti veya seçme özgürlüğünün derecesi temelinde farklılaşırken 1970’li yıllarda dahi

\footnotetext{
29 Eylül, Bulgaristan'da 1944'deki Komünist Ayaklanmasının başarıya ulaşmasının yıl dönümü olarak 1989 yılına kadar milli bayram olarak kabul edilmiş ve kutlanmıştır.
} 
"Bulgaristan'da bir geleceğim kalmadı." ve "Çocuklarım için Türkiye'ye gitmeliyim." düşüncesine tüm katılımcılarda rastlanmaktadır.

Biz Türkiye bilmiyoruz. Biz okuyorduk o zaman; ama babam çok söylüyordu: "Sağken ben bu çocukları nasıl götürebilirim?" diyordu. Bizim gö̈çmen olarak imkânsızdı. Amca vardl; ama öyle bir düşüncesi yokmuş. Bir de annesi, babası ya da çocuğu olanlara öncelik tanıyorlardl. Biz hepimiz oradaydık. Biz buraya geldikten sonra kardeşlere de istek yapma hakkı verdiler. (Yaş 69, Göç yılı 1972) Göç etme kararımız haliyle, memleket, Türkiye dedin mi herkesin içi yanıyordu, Türk'tün. (Yaş 73, Göç yılı 1978)

İsimler değiştikten sonra bazı insanlar gizli gizli Avrupa'nın Sesi Radyosu'nda seslerini duyurmuşlar. Naim Süleymanoğlu Türkiye'ye kaçtı. Turgut Özal'ın desteklemesi, buradan insanların açlık grevlerine başlaması, zaten farkina vardık bunların. Dediler ki "Kapılar açılacakmış, Türkiyecilik olacakmış". Ben tabi inanamadım; ama pasaport kuyrukları başladı. Herkes gizli gizli fotoğraf çekiniyordu pasaport için. Dilekçe gibi diyeyim, pasaporta başvuru için kâğıtlar vardı, yurt dışına çıkış için. O pasaportla Avrupa'ya da gidebilecektin. Biz Türkiye'yi tercih ettik, en azindan dil, din ayn. Babam "Ben 69'da niyetlendim gelemedim" dedi. "78'de niyetlendim; hep eşyalarımı topladım, sinırlar kapandı" dedi. "Ben Avrupa ülkelerini düşünmüyorum, benim hayalim Türkiye'ye gitmek, siz de kardeşlerinizden ayrilmayın" dedi. Babamı dinledik, onunla birlikte Türkiye'yi tercih ettik. (Yaş 49, Göç yılı 1990)

Göçmenler, göç yolculuğuna, aile üyelerinden bazılarını geride bırakarak çıkmışlardır. Bir katılımcı ise tek başına ve düzensiz yollarla göç etmek zorunda kalmıştır. Göçler, "göçmen olarak, istekle", "turist olarak gelip kalma, vize ile", "1989'daki sınır dışı edilme" ve "kaçak" olarak çeşitli nitelemelerle ifade edilmektedir. Göç yolculukları süresince hemen her zaman bir noktaya kadar veya bir noktadan sonra otomobil kullanılmış olmakla birlikte 1970'li yıllardaki göç sürecinin baskın vasıtası trenler olmuştur. Daha sonraki göçler tek başına otomobil veya otobüsler aracılığıyla gerçekleştirildiği gibi "1989'daki sınır dışı edilme" sürecinde ve "kaçak" göçte kamyon ve kamyonetler de kullanılmıştır. Göç yolculuğu kimi zaman önceden toplanıp sandıklarla trenlere yüklenen eşyaların ardından kimi zamansa birkaç gün bazen birkaç saat içinde toparlanan birkaç eşya ile birlikte gerçekleşmiştir: Düzensiz göç sürecinde ise katılımcının yanına alabildikleri ufak bir sırt çantasının içindeki birkaç "abur cubur", kimlik ve pasaportla sınırlı kalmıştır. Bir şeyler getirebilme fırsatının olduğu durumlarda genellikle gidilen yerde satılıp paraya 
çevrilebilecek şeyler ya da olası riskleri azaltmak, "aç kalmamak" adına g1da maddeleri, erzak tercih edilmiştir. Geride bırakılmasından üzüntü duyulanlar arasında aile büyükleri ve "ev"ler başta gelirken bunlara toprak, hayvanlar, ağaçlar ve çiçekleri de eklemek mümkündür:

Tütünleri tarlada bıraktık. Doğru çocuklarla bindik. Birer çanta aldık yanımıza, sadece. Bize vize vermediler ya biz misafirliğe gelip kaldık. Dönmedik gayrı. (Yaş 62, Göç yılı 1992)

Biz tamamen evi bırakıp geldik. Hiçbir şey getiremedik. Herkes giyecek eşyaların aldı. Hiç para da vermiyorlardı, yasaktı. Yanımıza yiyecek aldık. [...] Gece çıktık yola. Öyle söylediler. Gece gidin dediler. Önce dedemin elini öpmeye gittik. Onu çok kötü hatırlıyorum. Dedemle çok ağladık. Dedemin, anneannemin elini öptüm. Geri kalanın o kadar vicdan yapmadım; ama dedemle nenemi hiç unutamadım o zaman. (Yaş 69, Göç yılı 1972)

Anneannemle dedem, anneannem ile dedemi çok fazlada sevdiğim için, onlar neden orda kalıyor diye düşündüm. Şu an da onu anımsadım. Dedem getirmişti bizi trene. Bize "Geri gelmeyeceksiniz, biz geliriz." demişti. Şu anda tamamen dedemi hatırladım. [...] Dedemin bizi getirdiğini, yolcu ettiğini, el salladı̆̆ını hiçbir zaman unutmadım. Onlarla beraber gelmek isterdim. (Yaş 55, Göç yılı 1973)

Bursa'nın kalıcı adres olarak tercih edilmesinin en önemli nedeni, aile üyelerinden daha önce gelenlerin bu kentte yerleşmiş olmasıdır. Yanlarına gelinen akrabalar; anneanne, abla ve dayıdan babaannenin kız kardeşinin oğluna kadar çeşitlilik göstermektedir. Göçmen aileler, bazen hemen ertesi gün, bazen "on yedi gün” sonra bazense birkaç ay kadar sonra kiraladıkları evlere taşınmışlardır. Bursa'ya daha önce yerleşmiş olan akrabalar, kiralık ev bulmada olduğu kadar bazen birer çantayla gelmiş olan akrabalarına "yorgan, döşek" gibi eşya yardımında da bulunmuştur. Tüm göçmenler ailelerinden çalışabilen herkesle birlikte iş yaşamına katılmış ve yeni hayatlarına bu yolla tutunmaya, geldikleri yerde bir yer edinmeye çalışmışlardır. Okul çağında olan iki katılımcı hem ekonomik sorun ve sorumluluklar hem de dil ve kimlikle ilgili uyum problemleri nedeniyle öğrenim hayatlarına devam etmekte sıkıntılar yaşamışlardır. Bir katılımcı kimliğinin çıkarılamayışının yanında ekonomik sebeplerle Türkiye'de hiç okula gidemezken diğeri ise ortaokuldan ayrılıp çalışma yaşamına katılmak zorunda kalmıştır. Kadınlar sürekli bir iş bulamadıkları durumlarda "kır işi" olarak tabir ettikleri mevsimlik tarla işlerinde, erkekler ise inşaat sektöründe çalışmış, düzenli bir fabrika işi bulduklarında dahi pazar günleri bu işlere gitmeyi 
sürdürmüşlerdir. Çalışılan işler göçmen kadınlar açısından bakıldığında, tekstil sektöründe bir süreklilik gösteriyor gibi görünse de Türkiye'deki işler, Bulgaristan'da eğitimleri alınan ve/veya çalışılan desinatörlük, kalıp çıkarma, deseni çözgü makinalarına aktarma gibi daha kalifiye işler yerine, vasıfsız işler olmuştur. Tekstil sektörüne bir de Bursa'da gelişmekte olan otomotiv sektörü eklenmiştir. İş bulmada akrabaların desteği görülmekle birlikte, kimlik problemlerine rağmen işe alma ve sigortalılık sürecinde devletin esnek politikaları göçmenlere kolaylık sağlamıştır.

Desinatör için de Gabrovo'da okumuştum. Mesleğim güzeldi. Hatta buraya geldikten sonra da devam ettirebilirdim; ama arkan olmayınca bir yere gidemiyorsun. Malcılar'a başladım. O senelerde fuel-oil kıtlığı vardı, 1978, 1979, 1980 senelerinde. Orası kapandı, sonra Farba'ya başladım. Ordan da emekli oldum. (Yaş 73, Göç yıll 1978)

Annemle birlikte önce kır işlerine gittik, armut toplamaya. Annem yanına götürüyordu. 13 yaşındaydım; ama büyük gösteriyordum, herhalde. Yarım yeumiye veriyorlardı. Annemle çalışıtım bir sene gibi. Sonra başka akrabalarm yanına girdim, çalıştım. (Yaş 39, Göç yılı 1992)

\section{Göç Süreci II: Beklentiler, İlenimler ve Sorunlar}

Türkiye'ye dair izlenim ve beklentiler, Türkiye hakkındaki bilgilenme olanakları çerçevesinde zaman içinde değişiklik göstermiştir. Önceleri hemen hemen tek bilgi kaynağ1; daha önce, özellikle 1951'de, Türkiye'ye göç etmiş ve ziyarete gelen ya da geri dönen komşu ve akrabalara ek olarak oradaki Türk ve Bulgar yönetici ve öğretmenlerin söylemleriyken; zamanla, sinırlı da olsa video-kasetlere ve Türk televizyon kanal(lar)ına ulaşma imkânı doğmuştur. Ancak, bu imkân doksanlı yılların ikinci yarısına kadar, Bulgar yönetiminin dışa kapalı politikaları ve asimilasyon stratejisinin gölgesinde, sınırlı kalmıştır. Doksanlı yılların sonunda ise Türk televizyon kanallarının izlenebilmesine rağmen hayaller, alışılagelmiş yaşamı sürdürmek üzerine kurulmuş ve zihinlerde bahçeli evlerden oluşan yerleşimlerin imgeleriyle Türkiye'ye göç edilmiştir.

Bize Bulgaristan'dayken hep öğretmenlerimiz söylüyordu. "Oraya vardığını zaman sizi dağlara kaçıracaklar, faşist ülke" diye anlatıyorlardı Türkiye'yi. Buraya geldiğimiz gibi öyle olmadığın gördük. Bizi gayet insan gibi karşıladılar. (Yaş 68, Göç yılı 1971) 
Biz, Ferdi Tayfur'un, Orhan Gencebay'ın arabesk filmlerinden biliyorduk Türkiye'yi. Kaset alıp gizli gizli izliyorduk o dönemde. Belirli evlerde yayın yapıyorlardı. Üç beş kişi ikişer leva verip falan adreste bilmem kim Türkçe film izletiyormuş, kaset varmış diye giderdik sinema gibi izlemeye. (Yaş 49, Göç yılı 1990)

Biz, Türk kanalları izliyorduk. Bir bizim köyde tutuyordu. Eşim de biraz televizyondan anlardi. Kurcalıyordu kurcalıyordu, bakıyorduk; ama annemin köyünde bakılmazdı. Bize geliyorlard, izliyorduk. Çok nadir insan bakabiliyordu. O zaman yasaktı zaten Türkçe televizyona bakmak. Radyoyu bile salamazdık, Türkçesini duyacaklar sokaktan geçenler diye. (Yaş 62, Göç yılı 1992)

Biz televizyonda zaten görüyorduk. Türk kanalların izlemeye başladık. Dizilerini görüyorduk, her şeyini görüyorduk. Ailemden buraya gezmeye gelenler de oldu, akrabamız. Az çok nasıl bir yer olduğunu biliyordum, ama hiç bu kadar binaları birbirine yakın birleşik, bu kadar basık ve kalabalık bir yer beklemiyordum. Hep müstakil ev, her tarafi açık, geniş bahçeli bir yer bekliyordum. Oradan biraz bir hayal kırıklığı yaşadım; ama kalabalık bir ülke olduğunu biliyordum zaten. (Yaş 38, Göç yılı 1998)

Göçmenler, Türkiye'ye geldikleri dönemde yaşadıkları uyum problemlerinden ve iş yaşamındaki sıkıntılardan, özellikle kadınların çalışmasıyla ilgili tutumlardan bahsetmenin yanında, her şeye rağmen hayatlarını yeni baştan kurdukları ve çok çalıştıkları bu dönemde bile, Türkiye'de Bulgaristan'daki çalışma temposuna göre rahat ettiklerini ve daha çok ürüne ulaşabildiklerini belirtmişlerdir.

Doksanlı yıllar çok farklıydı. Biz geldiğimizde kadınların çalışması çok yadırganıyordu, ama biz tek erkeğin çalışmasıyla ayakta kalamazdık. Orada da çalışıyorduk. Burada da çalışıp daha çabuk toparlanıp kendi evimiz olsun istedik. (Yaş 49, Göç yılı 1990)

Bizim zamanımızda orada pazar diye bir şey yoktu zaten. Her şeyi kendimiz yetiştiriyorduk. Ufacık bir yer vardı yalnız. Karpuz, kavun satılıyordu. Onu hatırlıyorum. O da al alabilirsen. Dedem rahmetli, geceden saat üçte straya giriyordu. Bir çuval karpuz getirdi, kabak çıktı. Attık yiyemedik. Onu hatırlıyorum. Çok mutluyduk biz geldiğimiz için; çünkü babam öyle konuşuyordu [...] Allah vergisi Türkiye, ama kıymetini bilemiyoruz. Yemeden göz doyuyor. Orada bizim zamanımızda çalışırsan var. Ekersen var, biçersen var. Hayvana bakarsan sütün var. Şimdi baksan da bakmasan da kapıya geliyor. Buradaki rahatlık bir yerde yok, oğlum. Kim ne derse desin. Değil mi? (Yaş 69, Göç yılı 1972) 


\section{Göç Sonrası: Kente Alışma/Uyum}

Göçmenlerin, hasretle andıkları konuların başında, ağaçtan kendi yetiştirdikleri meyveleri toplamak veya toprakla uğraşmak gelmektedir. Bu ürünleri pazardan belli miktarda almak zor gelse de diğer yandan ekip dikmedikleri birçok şeye aynı anda ulaşabiliyor olmayı, "rahatlık" olarak tanımlamaktadırlar. Kırsal yerleşimin alışkanlıkları ve yeşile hasretin yanında kendi taze yumurtalarının; süt, yoğurt ve peynirlerinin olmayışı en çok yokluğu hissedilen şeyler olmuştur. Önceleri lutenitsa (kahvaltılık salça), kuşburnu marmelatı, vafla (gofret) gibi ürünleri "aradıklarını"; ancak artık eskisi kadar özlemediklerini belirtmişlerdir. Katılımcılardan biri, kendisinin ve oğlunun köpeklerini özellikle hatırladıklarını belirtirken, bir diğeri ise adeta tüm memleket imgesini, geride bırakılan her şeyi, ineği ile özdeşleştirircesine yıllarca onu hasretle andığını, özlediğini, rüyalarında gördüğünü belirtmiştir. Yalnızca Madan'da, apartmanda oturan bir göçmen kadın, Bulgaristan'da haftada bir sinemaya birkaç kez de kafeye gittiğinden; ancak Türkiye'ye geldikten sonraki hayatında bu tarz şeyleri hiç yapamadığından bahsetmiştir:

Ineğim vardl; tavuklar, yumurtamız vardl, taze. Evin etrafı çok genişlikti.

Salıyorduk balkana kendileri gelirlerdi akşama inekler, sağıyorduk. Tazeydi her şey. Baya bir zor alışık. Oğlan, baya bir zor alıştı. Nerede oradaki sütler, yoğurtlar, diye. Oğlan "Söyle de babaanneme oradan bize yoğurt yollasın" dedi. Buradan alıyoruz; ama ne kadar aliyoruz. Bir yudum. Orada tencerede, ucundan yerlerdi. [...] Her şey aranıyor, tabi. Her şey kaldı orada. O yok, bu yok. Köpeğimiz vardı, büyük. Köpekle oğlanın bir arada resmi vardı. Onu getirdik. Oğlanın kedisi, köpeği aklına gelirdi. Köpeğimiz benle tarlaya gider benle eve gelirdi. Etrafima kimse sokulamazdr. Alametti köpek. (Yaş 62, Göç yıll 1992)

Buraya geldik Davutkadı'ya. Çıktık, Fatma ablalarm evine. Sevgin küçüktü. Teleferik taraflarnna götürdü bizi. Anaa, dedi. Kapayın gözlerinizi, dedi. Görmeyelim bu çayırı, dedi. Yeşillik, boşluk, çayırlık öyle alışı̆̆ız. Buraya gelince yalnız ev gördük, harem gördük, kapı gördük, kiremit gördük, taş gördük. (Yaş 78, Göç yilı 1973)

Burada göçmen yoğun mahallelerde olduğu kadar, diğer yerlerde de yaşamış ya da yaşamakta olan kadınlar, ilk yıllarda bir takım ayrımcı söylemlerin olabildiğini; ancak artık kendileri için "göçmen" ya da "yerli" ayrımının kalmadığını ve bu tanımlamaların da eskisi kadar sık tekrarlanmadığını belirtmişlerdir. Ancak, komşuluğun göçmen-yerli 
ayrımından çok (modern) kent yaşamı temelinde giderek kaybolan bir olgu olduğu görüşmelerin ortak vurgusu olmuştur. Göçmenler geldikleri yıllarda yine yardımlaşma temelinde sıcak komşuluk ilişkilerinin kurulduğunu; ancak günümüzde bunun giderek azaldığından hatta yok olduğundan bahsetmişlerdir.

Oldu Bursa'da komşularımız ve çok fazla destek oldular. Sanki aileden biri gibi davranıyorlardı o zaman. Bir kasanın içinde getirmiştik. Televizyonumuz vardl; ama onların hepsini satmışıtk. Burada, komşularda seyrederdik. Akşam olduğu zaman televizyona çă̆ırırlardı. Şimdi kalmadı komşuluk. (Yaş 55, Göç yıll 1973)

Katılımcılar, Bulgaristan' dan getirdikleri anı değeri taşıyan ya da halen kullanılan bir eşya olup olmadığı sorulduğunda, fotoğraflar ve dikiş makinası dişında daha çok yorgan, döşek, patik, tülbent gibi çeyizlik eşyaların olduğunu belirtmişlerdir. Ancak, bir şekilde yanlarında eşya getirebilenler ya da kendileri getiremese bile yakınlarından yollamayı başaranlar, ilk yıllarda soba, yatak, kilim ve dibek gibi pek çok Bulgaristan'dan getirilmiş eşyalarının olduğunu da ifade etmişlerdir. Bir kadın, Türkiye'de de ilk yıllarda yağ yapmaya devam ettiğini söylemiştir. $\mathrm{Bu}$ davranış yeni gelinen yere uyum sağlarken eski alışkanlıkların sürdürülmeye çalışıldığını göstermektedir. Katılımcların hepsi arsa alarak kendi evlerinin inşasında bizzat çalışmışlardır. Mekânda böyle bir dönüştürücü güce sahip olunması da yeni gelinen yere aidiyet hissedilmesini sağlayan önemli bir unsur olmuştur. Bununla birlikte ilgili göçmen grubunun geldiği yere aidiyet hissetmesi, göç ettiği yere/mekâna uyum sağlamaya başladığı sonucunu da ortaya koymaktadır.

Üzerinden yıllar geçmiş olsa bile tüm göçmenler, "Yılın bu zamanı orada olsaydınız ne yapıyor olurdunuz?" sorusuna, "Mart ayı, fideleri ekmeye başlardık, tütün için; patatesleri ekerdik." cümlesine benzer cevaplar vermişlerdir. Köy yaşamıyla ilgili hatıralar zamansal bağlamlarıyla birlikte oldukça canlı bir şekilde hatırlanmaktadır. Ancak, anıların hatırlanması ve paylaşılması birlikte yaşanmış olmasıyla ilişkilendirilmiştir. Burada bayramlar, düğünler öncelikle aile büyüklerinin orada bırakılmasıyla daha sonra da zaman içinde eski anlamlarını yitirmiştir. Her bir kadına, buradaki bayramlar, dügünler hakkındaki fikirleri sorulmasına rağmen hiçbiri bu konular üzerinde durmamış, Türkiye'de 1 Mayıs'la ilgili bir hatıralarına da rastlanılmamıştır. 
En son yaşananı anlatayım. İki gün önce amcamın kızı geldi, eşi ve çocuklarıla birlikte. On dört yıldır görüşmemiştik. Şimdi hep oradaki yaşam konuşuluyor. Daha çok bilenlerle konuşuyorsunuz. Genelde aileden biri oluyor bu; çünkü çocukluğumdaki arkadaşlarımin hepsi dağıldı. Çocukluğumu geçirdiğim bir arkadaşım yok çeoremde. Öyle olunca anlatamıyor insan çok. (Yaş 38, Göç yılı 1998)

Tüm göçmen kadınlar, görüşmelerin doğal seyri içinde hatırlama ve rüya ilişkisini kurmuş ve göç öncesi yaşamlarıyla ilgili rüyalarından bahsetmişlerdir.

Ohoo, Dedeler'i bile rüyamda görüyorum. İsollar'ı pek görmüyorum da. Şeytan Köprü'yü görüyorum. Tarlalarımı görüyorum. İsollar'ı da görüyorum da yine, Dedeler'i daha çok görüyorum. Gençliğimi de görüyorum. Çocukluğumu da görüyorum. Koyun da güdüyorum. Hepsini yapıyorum. (Yaş 78, Göç yılı 1973) Ya rüyalarma giriyordu aslında. Buraya geldim, hep orda görüyordum kendimi. Orada hayal ediyordum. Ay çok özlüyordum, yani. Oradaki doğduğum evi görüyordum. Bir uyanıyordum ay yine gitmemişim. Çok gitme hevesim vardl. Sicağına görmü̈s olsaydım belki çok özlem duyardım; ama bir 15 yıl geçtiği iç̧in hiç etkilenmedim. (Yaş 39, Göç yılı 1992)

Katılımcılara, Türkiye'de onlarla birlikte nelerin değiştiği ve katkıları sorulduğunda, öncelikle kadınların çalışma yaşamına katılmasında paylarının olduğunu düşündüklerini ifade etmiştirler. Bunun yanında, yemek alışkanlıkları ve özellikle konserve yapımının kendileriyle birlikte geliştiğini, geldiklerinde buradaki komşularının konserve yapmadıklarını, onlarınsa köy yaşamında üretilen çok miktardaki ürünün kış aylarına saklanması için buna alışkın olduklarını ve burada bu üretim söz konusu olmasa da konserve yapımını devam ettirdiklerini belirtmişlerdir:

Burada su böreğini pek bilmezlerdi. Biz öğrettik, hâlâ da meşhurdur bizimki. Kaçamak, kaşa, kapama bunlar bizim oradan gelen yemeklerimiz. Her çeşit konserve yapıyorduk orada da. Burada biz geldiğimiz zaman hiç yapılmiyordu. Hazır varsa belki bilmiyorum; ama biz kendimiz yapıyorduk. (Yaş 68, Göç yılı 1971)

Mahallemde pek göçmen yok benim oturduğum yerde. Burada benden çok yemekler, su börekleri, konserveler öğrendiler. Önümüz boşluktu, her türlü salçalar yapıyorduk. Herhangi bir salça tavası veya kürek almaya beni götürürlerdi komşularm. O tür alı̧verişlerimiz oldu. (Yaş 73, Göç yılı 1978)

Bulgaristan ziyaretleri söz konusu olduğunda ise, eski yıllarda oldukça nadir gerçekleştiriliyor olmasına karşın, günümüzde emekli maaşı 
imkânları, çifte vatandaşlık, Bulgaristan'ın Avrupa Birliği üyeliği gibi sebeplerle ziyaretlerin sıklaştığını söylemek mümkündür. Ancak, hiçbir katılımcı, oraya tamamen yerleşmeyi ya da emekliliğini geçirmeyi düşünmemektedir. Ziyaretler, çifte vatandaşlık süreçleri için aksi gerekmediği takdirde 10-15 günden fazla sürmemektedir. Bir göçmen kadın annesinin çok genç yaşta öldüğünden ve onun mezarını ziyarete gittiğinden bahsetmiştir. Çocukluk ve gençlik yıllarının geçtiği mekânlar olması gidişlerdeki etkenler arasında sayılmakta ve "evler" bu mekânlar arasında özel bir vurguya sahip gözükmektedir.

O zamanlar hiç gidilmiyordu. Dedem vefat ettiğinde bile biz çok zor gitmiştik. Hani böyle gitme gelme diye bir şey yoktu. Ben dedemin cenazesinde gidememiştim. Rahatsızlı̆̆ında gitmiştim. Uzun zamandır buradayım, küçük geldim, ama bir kere gittim. (Yaş 55, Göç yılı 1973)

Ben bir 1975 ve 1979'da gittim. Bir daha 2016'da gittim vatandaşlı için. AB'ye girdi ya orası, ondan gittik. Başka türlü hiç gitmezdik. Beni oraya bă̆layacak hiçbir şey yok. Ev satıldı, yerler satıldı. Hepsi gitti yani; ama köyünü özlüyor insan. Doğru evime gidiyorum buradan. Yaşadığım evime gidiyorum. Orada bir sürü anılarım var. (Yaş 68, Göç yılı 1971)

Geldiğimizde baya bir zor alıştık, ama şimdi de ötede duramam ben. Gitsem de duramam. Ben bir hafta, on gün kalsam, onuncu günde geliyorum. Buraya alıştık artık. Orası zaten sınırı geçince kapkaranlık. Buraya geçince bütün her yer ışık. Aydınlık geliyor. Öteye gitsek yaşayamayız. (Yaş 62, Göç yılı 1992)

Çocukluk ve gençlik dönemlerine dair anılar, yaşanan yer ve çevrenin özellikleriyle birlikte hatırlanmaktadır. Dolayısıyla üzüntü veren anıların yeniden canlanmasını engellemek, ancak bu yer ve çevreden uzak kalmakla mümkün görünmektedir.

Şimdi kendimi bildim bileli köyümün en küçük taşına kadar hatırlıyorum. Belki de eşimi kaybettiğimden yalnız kaldı̆̆ımdan. Her tarafi çok fazla hatırlıyorum. Topladı̆̆ım çiğdemleri, gelincik mantarlarını... Dedeler'de pınarlarımız vardı. Pınarların içinde alakene derdik, kendi siyah üzeri sar benekli, burada hiç görmediğim hayvanlar. Bütün ă̆acını, taşını, çeşmesini her şeyini hatırlıyorum. Buradan gezmeye gittiğimde, şu anda çifte vatandaşım, eşim sağhlı̆̆ında ilkokulu bitirdiğim köye götürdü, yıkılmış. Yerinde kiraz ă̆açları çıkmış. Oradan başka bir köye, ortaokulu bitirdiğim köye götürdü. Okulum yıkılmış, kapısı penceresi kalmamış. Köyde insan yok. Üzücü. Şu anda Bulgaristan'ın hele bizim tarafin insanları her şeye muhtaç. Anılarım çok olduğu için pek tazelenmesini de istemiyorum. O yüzden maaş dışında pek gitmek istemiyorum. (Yaş 73, Göç yılı 1978) 


\section{Sonuç}

$\mathrm{Bu}$ çalışma, hatırlama ve unutma edimlerini, bir göçmen grubun hafızasıyla ilişkili olarak ele almaktadır. Sahip olunan felsefî mirasın ışığında hatırlayanın kim olduğu sorusuna net bir yanıt vermek mümkün olmamakla birlikte, bugün bireysel hafızaların tam anlamıla özgün ve tekil olmadıkları ortak bir kabul halini almıştır. Ayrı ayrı kavranan faillerin anıları dahi, gruba ait izler taşımaktadır. Bu sebeple bir göçmen hafızasından bahsetmek mümkündür. Hafıza konusundaki bir diğer ortak kabul ise, onun geçmiş olayların saklandığı bir yer olmayıp, hatırlama anının özellikleri ile yeniden şekillendiğidir. Bu nedenle hatırlamayı etkileyen mekânsal yer değiştirme (göç gibi) ve grup etkileşimleri, bu çalışmanın odak noktasını oluşturmuştur.

Dügünler, bayramlar ve panayırlar gibi anma törenlerinde pekişen grup etkileşimleri ve tütün üretimi gibi bedensel pratikler, toplumsal hafızanın önemli taşıyıcılarıdır. Toplumsal hafıza ya da grup hafızası, törensel pratikler gibi alışkanlığa dayalı grup etkileşimlerinde -ya da literatürdeki karşılığıyla alışkanlık belleğinde- olduğu kadar araçsal olarak bedene, kıyafetlere, nesnelere ve mekâna sinmiş halde bulunabilmektedir. Mekândan bağımsız bir hafızadan bahsetmek mümkün değildir. Mekân, hafızanın hem oluşumunda hem saklanmasında hem de geri getirilmesinde, üzerinde gerçekleşen toplumsal ilişkilerle birlikte önemli bir rol oynamaktadır. Bu nedenle göç gibi bir yer değişikliğinde hafızanın çerçeveleri yerinden olmakta ve gelinen ülke koşullarında- yeniden şekillenmektedir.

Göç, mekânsal bir yer değişikliği olduğu kadar göçmen grubun hafızasında baskın bir anıdır; anılar, ortaklaşanların sayısı ile baskın hale gelmektedir. Göçe dair anılar, aynı zamanda duygusal heyecan yaratan bir sürece ilişkin olmaları nedeniyle göç kararından, göç yolculuğuna ve yeni gelinen yere uyum sürecine değin "resim kadar canlı" kalıp tüm detayları ile hatırlanmaktadır. Bu da "flash anılar"ın bir özelliğidir. Göç sürecine dair geride kalanlarla hesaplaşmayı içeren olumsuz duygusal içerikli anılar, göçmen grubun hafızasında belirgin duygusal içerik taşımayanlara göre daha fazla yer kaplamaktadır. Bu araştırmada gözlemlenmiştir ki, göç fırsatlara değil, belirsiz bir geleceğe doğru gerçekleşmektedir. Göçteki belirsizlikleri en aza indirmenin yolu ise, 
gidilen yerdeki akrabaların varlığına dayalı olarak toplumsal bir ağ kurulmasıdır. "Ortak büyük grup kimliği"ne sahip olmak ya da devletin işe alma sürecinde gösterdiği kolaylıklar da göç sonrası süreci kolaylaştıran etkenler arasında sayılabilmektedir. Göçe dair tarihsel sınıflandırmaların ötesinde, her göç deneyimi özgün süreçler içermekte, ancak yine de göçe dair grup hafızasında ortaklaşmalar belli temalar çerçevesinde toplanmaktadır.

Bulgaristan'dan göç sürecini bir yönüyle kırdan kente göç olarak ele almak mümkündür. Göçle birlikte mekânda gerçekleşen değişim, komşuluklar gibi grup etkileşimleri ve üretim ilişkilerindeki değişimi beraberinde getirmiştir. Köylü/kasabalı grubun toprak, tarla ve bahçe mekânlarıyla iç içe geçmiş hafızası ve bir yıllık döngüsünün tüm aşamalarına hâkim olduğu tütün üretiminin yerini, gelinen yerdeki (modern) kent yaşamının hızı ve seri üretimin meydana getirdiği emek sürecinde "yabancılaşma" almıştır. Bu değişim, göçten sonrasına dair hatırlananların, göç ve öncesine göre oldukça sınırlı kalmasında etkili olmuştur.

Çalışmanın bulgularında görüldüğü gibi, göçten önceki yaşamlarında köy hayatını deneyimlemiş ve tarımsal üretime katılmış olan kadınlar, yalnızca geçimlik üretim yapmakla kalmamış, mutlaka "tütün işlemiş"lerdir. Köy hayatının gerektirdiği işler, tarımda makineleşmenin eksikliği ve tütün tarımının çok zahmetli bir iş oluşu, Abadan-Unat'ın (1986, s. 186) "işlevsel geniş aile" olarak nitelendirdiği aile tipini ve imece temelinde güçlü komşulukları getirmiştir. Komşuluk ilişkileri yeni gelinen yerde (burada Bursa) de sürdürülmüş ancak kent yaşamının gereklilikleriyle zaman içerisinde zayıflamıştır.

Tüm kadınlar, akrabaları ve komşularıyla ya da diğer köy/kasaba halkıyla bir arada oldukları törensel pratikleri uzun uzadıya anlatmışlardır. Hepsinin hafızalarında canlılığını koruyan önemli bir zamansa, Bulgar yönetiminin en baskıcı asimilasyon döneminde dahi Türk halkı tarafından coşkuyla kutlanmaya devam eden 9 Eylül olmuştur. 9 Eylül, komünist yönetim için 1944'deki zaferin y1l dönümü iken, Bulgaristan'daki Türk halkı için bir yıllık ürünün hasadının yapılması ve işlenmesinin ardından gelen eğlence ve bolluk zamanıdır, panayırdır. Panayırlar, bu yönüyle salt bir eğlence değil bir yıllık çalışmanın 
ödüllendirilmesidir. Bu noktada panayırlar, bu çalışma kapsamında toplumsal belleğin taşıyıcısı olmaları yönüyle değerlendirilmektedir.

Katılımcılar, geldikleri yerde ailelerinden çalışabilen herkesle birlikte iş yaşamına katılmış ve bu konuda devletin esnek politikaları, işe alma ve sigortalılık işlemleri için kimliklerin beklenmemesi, hızlıca formel sektörün içine alınmalarını sağlamıştır. $\mathrm{Bu}$ durumun göçmenlerin yaşamlarına olduğu kadar kent ekonomisine de katkı sağladığ düşünülebilmektedir. Kadınların, iş yaşamları, "tekstil sektörü" başlığ1 altında ele alındığında süreklilik gösteriyor gibi görünse de genellikle Bulgaristan'da çalışılan ve/veya eğitimi alınan alanlardan farklı, daha vasıfsız işlerde çalışmak zorunda kalmışlardır.

Sorulmasına rağmen, hiçbir katılımcı buradaki düğünler, bayramlar veya ramazan ayları gibi özel zamanların üzerinde durmamışlardır. Bu zamanlarla ilgili özel bir anı hatırlamamış/aktarmamışlardır. Buna karşın "Yılın bu zamanı orada olsaydınız ne yapıyor olurdunuz?" sorusuna aradan hiç vakit geçmemiş kadar canlı bir hafızayla ve tüm detaylarıyla yanıt vermişler, köy hayatına ve tarla işlerine dair pratikleri sıralamışlardır. Zira gelinen yerdeki (modern) kent yaşamı ve kapitalist üretim süreci kendine özgü unutkanlıkları beraberinde getirmiştir.

Türkiye'de onlarla birlikte nelerin değiştiği sorulduğunda öncelikle kadınların çalışma yaşamına katılmasındaki katkılarından daha sonra ise başta konservecilik olmak üzere yeme içme alışkanlıklarındaki kültürleşmeden bahsetmişlerdir. Konservecilik, hakkındaki deneyimlerini, Bulgaristan'da kendi ürettikleri ürünlerin kış ayları için saklanması gerekliliğiyle açıklamışlardır.

Bulgaristan ziyaretleri söz konusu olduğunda, eski yıllarda oldukça nadir gerçekleştirilen ziyaretlerin, günümüzde emekli maaşı imkânları, çifte vatandaşlık, Bulgaristan'ın Avrupa Birliği üyeliği gibi sebeplerle sıklaştığını söylemek mümkündür. Ancak, ziyaretlerin süresi çoğunlukla 10-15 günü geçmemekte ve hiçbir katılımcı emekliliğini Bulgaristan'da geçirmekten ya da geri dönmekten bahsetmemektedir. Çocukluk ve gençlik yıllarının geçtiği mekânlara duyulan hasret, gidişlerdeki etkenler arasında sayılmakta, "evler" bu mekânlar arasında özel bir vurguya sahip gözükmektedir. Geride kalan evler, ağaçlar, toprak ve özellikle aile büyüklerine duyulan hasret, göç sürecinin bugün dahi duyguyla hatırlanan yanı olmuştur. 
Sonuç itibariyle bu çalışma, hatırlama ve unutmanın toplumsal bellek taşıyıcılarıyla ve yer değiştirmeyle ilişkisini Bulgaristan göçmeni kadınların anlatıları üzerinden ele almış, toplumsal hafızasının işleyişini göçle olan ilişkisi üzerinden tartışmıştır. Buna göre toplumsal hafızanın ontolojik tartışmalarından bağımsız olarak-, grup etkileşimlerinde ve mekânın yapılanmasında dağılabildiği ve bugünden kurulabildiği görülmüştür. 


\title{
EXTENDED ABSTRACT
}

\section{Remains in the Memory: Migration in the Narratives of the Immigrant Womens from Bulgaria}

\author{
Sercan Eklemezler \\ Bursa Technical University
}

Migration as a spatial displacement that divides the continuity of common experience can also be viewed as a "dominant memory" in group memory. Migration and the new urban life that comes with the migration change the migrants' perceptions and habits on time and space. In this context, the original effects of modern life that comes with migration to the city on remembering and forgetting are mentioned. However, remembered and forgotten are reproduced in a new context. The so-called new context coincides with the mourning process in Vamik Volkan's description. According to him, people who have experienced the relocation will be involved in a mourning process. In this process, the immigrant enters into a revenge through the memories of the lost place.

In this study based on the life experiences of women who immigrated from Bulgaria to Turkey, memory is discussed in the framework of relationship with a change of location (migration). Migration is basically a human mobility, which involves a spatial rupture. For this reason, migration studies have the responsibility to address the human being and the relationships that someone has created as a result of spatial mobility, and remember and forget what. It is emphasized that memory may be distributed to social interactions and space, in this study. Memories are reconstructed with spatial changes. For Halbwachs, it is difficult to find a person in the streets of a city because the crowds that fill the streets are moving and the streets are constantly relocating. Memories change and differentiate in relation to new memories.

Here, a qualitative research design was applied in accordance with the objectives of the study and in-depth interviews were conducted with the participants. In the first design of the study, it was aimed to reach the experiences of the male and female migrants about the migration process. However, the reluctance of migrant men and their limited narrative in the 
interviews led to the exclusion of male participants. The research group was formed by snowball sampling technique. If information about the participants included in the study is given; they all come from Kardzhali province of Bulgaria, which has a dense Turkish population, and settled permanently in Bursa. An important point to note here is that Kardzhali province is mostly composed of village and town settlements. So participants come from the villages and towns of Kardzhali and have been involved (modern) city life in Turkey. In the interviews ten female participants' -who migrated to Turkey from Bulgaria across different date ranges from 1971 to 1998- experiences on pre-migration, migration process and post-migration are discussed. Among the three processes -the village life in Bulgaria and the tobacco business that shaped it; the migration to Bursa and after the migration- the themes of living struggles and adaptation to new life came to the fore. The common emphasis of most of the participants about the pre-migration process is directed to the places where childhood and youth passed. Participants give information about their work as well as their spatial memories. The tobacco business is the most important one of them. Also, interpersonal relations such as the neighborhood are among the ones remembered about the pre-migration memories. The information that the neighborhood is important and widespread in the pre-migration process but started to decrease with the migrations experienced also takes place in the transfers of the participants. An important part of the memories of the participants was about the period defined as "when names change "or "when they change our names" that they lived in the phase of 1984-1989. The migratory voyages of the participants are also included in their memories. First of all, the common point of all participants is that they have carried out migration with the concern of the future in addition to political reasons. The postmigration process does not eradicate pre-migration experiences. Memories can include a green nature, food items such as wafers, a dog and/or a cow. With the sentence of "When we came here, we saw only houses, we saw 'harem', we saw doors, we saw tiles, we saw stones" one participant tells us that their pre-migration and post-migration experiences have changed as much as possible. As a result, this study, explores the relationship between remembering and forgetting with social memory carriers and relocation through narratives of immigrant women from Bulgaria. 
According to that social memory -independently from ontological discussions- can be dispersed in group interactions and structuring of space and established from today. Space plays an important role in the formation, storage and restoration of the memory, together with the social relations realized on it. For this reason, in the case of a spatial change, such as migration, the frames of the memory are displaced and reshaped under the conditions of the new country.

\section{Kaynakça / References}

Abadan-Unat, N. (1986). Women in the developing world: evidence from Turkey. Denver: University of Denver Press.

Adıgüzel, Y. (2016). Göç sosyolojisi. Ankara: Nobel.

Barash, J. (2007). Belleğin kaynakları. Cogito, 50, 11-22.

Bjork, R. (1975). Retrival as a memory modifier: an interpretation of negative recency and related phenomena. (R. Solso Ed.), Information processing and cognition içinde (s. 123-144). New Jersey: L. Erlbaum Associates.

Boyer, P. (2015). Anılar ne işe yarar? Hatırlamanın biliş ve kültürle ilgili işlevleri. (P. Boyer, ve J. Wertsch Ed.), (Çev: Y. Aşçı Dalar), Zihinde ve kültürde bellek içinde (s. 5-36). İstanbul: İş Bankası Kültür Yayınları.

Chambers, I. (2014). Göç, kültürr, kimlik. İstanbul: Ayrıntı.

Connerton, P. (1999). Toplumlar nasıl anımsar? İstanbul: Ayrıntı Yayınları.

Connerton, P. (2012). Modernite nasıl unutturur. (Çev: K. Kelebekoğlu). İstanbul: Sel Yayıncilik.

Eklemezler, S. (2018). Toplumsal hafiza ve mekan: Bulgaristan göçmeni kadınların deneyimleri ve Bursa Göç Tarihi Müzesi . Yüksek Lisans Tezi, Anadolu Üniversitesi, Sosyal Bilimler Enstitüsü, Eskişehir.

Halbwachs, M. (2007). Kolektif bellek ve zaman. Cogito, 50, 55-76.

Halbwachs, M. (2016). Hafizanın toplumsal çerçeveleri. Ankara: Heretik.

Huyssen, A. (1999). Alacakaranlık anıları: bellek yitimi kültüründe zamanı belirlemek. (Çev: K. Atakay). İstanbul: Metis.

Neyzi, L. (2011). Nasıl hatırlıyoruz-Türkiye'de bellek çalışmaları. İstanbul: İş Bankası Kültür Yayını.

Ricoeur, P. (2012). Hafıza, tarih, unutuş. İstanbul: Metis Yayınları. 
Roediger, H., Zaromb, F. ve Butler, A. (2015). Kolektif belleğin şekillendirilmesinde tekrarlanan hatırlamanın rolü. (P. Boyer ve J. Wertsch Ed.), Zihinde ve kültürde bellek içinde (s. 175-216). İstanbul: İş Bankası Kültür Yayınları.

Roseman, C. (1971). Migration as a spatial and temporal process. Annals of the Association of American Geographers, 61, 589-598.

Schacter, D., Gutchess, A. ve Kensinger, E. (2015). Belleğin özgüllüğü: Bireysel ve kolektif hatırlamanın etkileri. (P. Boyer ve J. Wertsch Eds.), Zihinde ve kültürde bellek içinde (s. 107-144). İstanbul: İş Bankası Kültür Yayınları.

Volkan, V. (2017). Göçmenler ve mülteciler: travma, sürekli yas, önyargı ve sınır psikolojisi. Ankara: Pusula Yayınevi.

\section{Kaynakça Bilgisi / Citation Information}

Eklemezler, S. (2019). Hatırda kalanlar: Bulgaristan muhaciri kadınların anlatılarında göç. OPUS-Uluslararası Toplum Araştırmaları Dergisi, 14(20), 667-698. DOI: 10.26466/opus.595302 